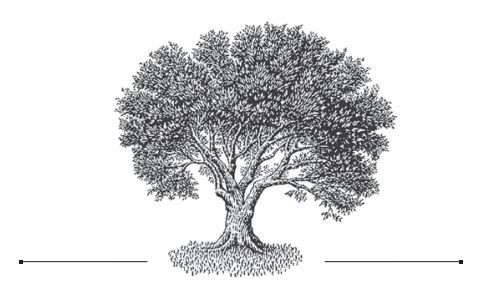

Идейное поле

"национального"

интеллектуала

имперского

периода: взгляды

Г. А. Полетики

(1725-1784)

на "украинскую

государственность" *

\section{Яков Анатодьевич}

\section{Дазарев}

Уральский федеральный университет им. первого Президента России Б. Н. Ельцина, Екатеринбург, Россия
The Ideological Basis of the "National"

Intellectuals of the Imperial Period: The Views of G. A. Poletika (1725-1784) on "Ukrainian Statehood"

\section{Yakov A. Lazarev}

Ural Federal University named after the First President of Russia B. N. Yeltsin, Yekaterinburg, Russia

\title{
Резюме
}

В статье затрагиваются дискуссионные вопросы формирования современной украинской нации и вдияния на этот процесс политической деятельности и сочинений Г. А. Полетики (1725-1784). Автор реконструирует контексты формирования взглядов Г. А. Полетики на историю “Малой

* Исследование поддержано программой 211 Правительства Российской Федерации, соглашение № 02.А03.21.0006.

Выражаю благодарность сотрудникам ИИиА УрО РАН канд. ист. наук, с. н. с. М. А. Киселеву и канд. ист. наук, н. с. К. Д. Бугрову за помощь, ценные советы и критические замечания, которые помогли мне в работе над текстом. 
России" и Войска Запорожского. Показывается, что дискуссии о правах и обязанностях дворянства, в которых активно участвовад Г. А. Полетика, не могли породить радикально нового подитического языка, который потенциально мог бы поставить под сомнение целостность Российской империи. Сделанные автором наблюдения позволяют утверждать наличие заметных разрывов в процессе строительства современной украинской нации.

\section{Ключевые слова}

Гетманская Украина, Российская империя, Г. А. Полетика, украинская казацкая элита, история Украины, малороссийские права, Войско Запорожское

\section{Abstract}

The paper deals with questions regarding the formation of the modern Ukrainian nation and, particularly, the impact of the political activities and writings of G. A. Poletika (1725-1784). The author reconstructs the context of the genesis of Poletika's views of the history of "Malorossiya" and the Zaporozhian Host. The paper shows that the debates about the rights and duties of the nobility, in which Poletika was deeply involved, could not produce radically new political language capable of questioning the integrity of the Russian Empire. This, in turn, derives from the fact that preservation of "Malorossiyan rights" was an important element of political bargaining for the Ukrainian Cossack elite. The purpose of this bargain was to consolidate the privileged position of the Cossack elite. In Poletika's writings, the ideal of the "Hetmanate" or independent "Ukrainian Cossack state," as well as feelings about the loss of the "Ukrainian state," was absent, even though this concept was common to all Malorossiyan social groups. The Cossack past was considered by Poletika as an "age of misfortune," in contrast to the Polish times. The author concludes that there were significant ruptures in the process of building the modern Ukrainian nation.

\section{Keywords}

Hetmanate, Russian Empire, G. A. Poletika, Ukrainian Cossack elite, history of Ukraine, Little Russian rights, Zaporozhian Host

Одной из наиболее актуальных тем в новейшей историографии является анализ процессов н а ц и е с т р о и т л ь с т в а, которые привели к появлению современных наций. С теоретической точки зрения, это подразумевает изучение интеллектуальных и культурных процессов, которые способствовали конструированию интеллектуальных проектов, вырабатывавших солидарность в понимании особого исторического прошлого (национальная мифология, “места памяти”, “исторические травмы”), развития государственности и уникального культурного развития. С практической точки зрения, при изучении процессов н а ц и е с т р о и т е л ь с т в а исследователь должен разрешить целый комплекс проблем, касающихся предпосылок и времени появления национальных проектов, степени их зрелости 
и завершенности, а также причин “победы” одного национального проекта над другим (другими).

В современной историографии наиболее известной социологической моделью, позволяющей осмыслить процесс нациестроительства в сравнительно-исторической перспективе, является подход чешского историка М. Хроха (Гроха). ${ }^{1}$ Данный подход появился во второй половине 1960-х гг. и касался возникновения национальных движений, итогом которых могло стать появление автономных национальных государственных образований [ХРох 2002: 125-127]. Особый акцент историк делал на ситуациях, когда “«чужеземный» правящий класс доминировал над этническими группами, которые занимали компактную территорию, но не имели «собственных» знати, политического единства или продолжительной литературной традиции” (имеются в виду территории Центральной, Восточной и Юго-Восточной Европы. - Я. Л.) [IBID.: 123]. По мнению М. Хроха, исторически в подобную ситуацию попадали и современные украинцы. Предложенный М. Хрохом подход (в оригинальном или модернизированном варианте) получил положительный отклик на Западе (в т. ч. в украинской диаспорной историографии), а также на постсоветском пространстве [ЕкЕльчик 2010: 120-124].

В рамках статьи мы не будет останавливаться на анализе проектов строительства украинской нации (федералистский и самостийный проекты), поскольку в западной и украинской историографиях дискуссии на эту тему все еще открыты [ЕкЕльчик 2010: 105-129]. Для нас будет важно то, что М. Хрох обозначил как прелюдию к процессу нациестроительства, когда закладывались предпосылки для появления нации [Хрох 2002: 128]. Именно в отношении этого периода, часто обозначаемого в украинской историографии как период национального Возрождения, существует определенный консенсус. Данный консенсус заключается в том, что “национальные” интеллектуалы, политические деятели данного периода сохраняли идеалы “украинской государственности”, особой национальной памяти, обращаясь к истории казацкого прошлого. Подобная интеллектуальная работа являлась реакцией на ликвидацию автономии Гетманской Украины (1764). Однако политика “кнута и пряника”, проводившаяся российским правительством, привела к расколу в украинской элите на традиционалистов (сторонники автономии) и ассимиляторов (сторонники ассимиляции и русификации региона). По своему политическому поведению традиционалисты не

1 Хотя сам М. Хрох рассматривал свою модель в качестве “эффективных методов, позволяющих классифицировать и оценивать опыт создания нации как процесса, происходящего в рамках более глобальной социальной и культурной истории" [XPOX 2002: 121]. 
ставили под сомнение лояльность российскому престолу, но в ответ на притеснения и репрессии малочисленные сторонники автономии в последние десятилетия XVIII в. стали собирать исторические документы и создавать исторические сочинения, подготавливая украинское национальное Возрождение и, соответственно, интеллектуальную базу для формирования современной украинской нации [Когут 1996: 261-263; Плохій 2013]. Такая интеллектуальная работа, связанная с экзистенциальным переживанием по поводу утраченной государственности, нашла свое отражение в популярном анонимном сочинении "История русов” (не ранее 1818 г.), повлиявшем уже в XIX в. на взгляды идеологов украинского национального движения из разночинной интеллигенции (Н. И. Костомаров, П. А. Кулиш, Т. Г. Шевченко). Следовательно, в рамках данной историко-социологической схемы снимается проблема разрывов в формировании модерной нации и выстраивается непрерывная линия становления украинского национального самосознания, изначально отличного от российского. ${ }^{2}$

Среди тех, кто подготавливал будущее украинское национальное Возрождение и способствовал формированию современной украинской нации, зачастую выделяют видного общественного деятеля и “национального интеллектуала” второй половины XVIII в. Григория Андреевича Полетику (1725-1784), происходившего из среды казацкой элиты (старшины) Гетманской Украины. ${ }^{3}$ Согласно историографической традиции, политические взгляды Г. А. Полетики, отразившиеся в его историко-политических сочинениях, интерпретируются как воплощение идей “малороссийской автономии”, “независимой/автономной Гетманщины/Украины”, “Украинской казацкой державы”, а сам он

2 Несмотря на популярность этой социологической модели, в современной украинской историографии появляются работы, в которых подвергается критике ее функциональность. В качестве уникального примера сошлемся на работы днепропетровского исследователя О. И. Журьы [2009].

3 По своему социальному статусу Г. А. Полетика был выходцем из среды правящей (казацкой) элиты Гетманской Украины. Его отец - Андрей Павлович - дослужился до чина бунчукового товарища. Сам Г. А. Полетика достиг должности “главного над классами инспектора" в Морском шляхетском кадетском корпусе (1764-1773). Среди талантов Г. А. Полетики современники отмечали его знание древних языков и истории. Эти качества были по достоинству оценены В. К. Тредиаковским и Г. Ф. Миллером в тот период, когда Г. А. Полетика работал в качестве переводчика при Академии наук и Синоде (1746-1764). За этот период им были подготовлены несколько переводов античных авторов и греческих богословских сочинений. В 1766 г. Полетику даже рекомендовали в качестве знатока славянской церковной истории известному исследователю древних русских летописей А. Л. Шлецеру, которому был нужен самый древний славянский перевод Библии. Однако подлинную известность Г. А. Полетике принесла работа в Уложенной комиссии Екатерины II (1767-1768), где он представлял шляхту Лубенского полка, а впоследствии стал лидером всей украинской (малороссийской) делегации [КАГАНов 1966: 140; Плохій 2013: 103-104; РуднЕв 2015: 363-371; ЛитвиновА 2015]. 
предстает как борец за “казацкие права”, “отважный лидер и искусный полемист” среди “украинских автономистов” [Когут 1996: 22, 160-169, 208-209; МЕльник 2003: 132, 134; ПлохІй 2013: 61, 104]. В связи с этим возникает ряд вопросов: как и насколько сильно рефлексировал Г. А. Полетика по поводу утраты “украинской государственности” / “казацкой автономии”, насколько политический дискурс, воспроизводимый данным политическим деятелем, отличался от российского, оппонировали ли его взгляды “российскому централизму”? Для ответа на эти вопросы нам придется обратиться к реконструкции идейного поля Г. А. Полетики, в рамках которого создавались его историко-политические произведения.

Как мы уже отмечали, Г. А. Полетика был выходцем из казацкой элиты Гетманской Украины. В связи с этим необходимо сделать небольшое пояснение. Территория, обозначаемая этим понятием, в российский политический лексикон вошла под общим названием Малой России. В это понятие входили территории и институты самоуправления Вой-ска Запорожского, местных православной церкови и шляхты, а также городских корпораций, обладавших жалованными грамотами на Магдебургское право. Такое разделение было закреплено в марте 1654 г. четырьмя жалованными грамотами. Согласно текстам этих соглашений, царю отводилась роль суверена над этими сословными группами. Для российского царя Войско Запорожское и население Малой России выступало в качестве подданных, а с неказацкого населения (мещан и крестьян) предполагалось собирать налоги в царскую казну. Однако в силу ряда причин управление и налоговый контроль практически над всей территорией Малой России было присвоено верхушкой Войска Запорожского. К 1710 г. за казацкими гетманами на официальном уровне и вовсе было признано главенство над регионом и “народом малороссийским”, а казацкие права легитимизируются в качестве прав всей Малой России (“малороссийских прав”) [ГРАмотА 1956; ЛАЗАРЕВ 2013А: 206-218].

Официальное признание гетманов и казацкой старшины в качестве господствующей привилегированной группы дополнительно ускорило процессы расслоения среди малороссийского казачества. Последнее приводило, по сути дела, к превращению рядового казачества в крепостных местной элиты, что также отразилось на боеспособности казацкого войска. На этом фоне в казацкой элите, стремительно превращавшейся в землевладельцев, начинают проявляться тенденции к 
закреплению своего привилегированного статуса, особенно во взаимоотношениях с “великороссийским” дворянством, с которым устанавливаются стабильные и плодотворные неформальные связи, позволявшие лоббировать личные интересы (решение имущественных и материальных вопросов, продвижение по карьерной лестнице) [ЛАЗАРЕв 2013Б]. Эти тенденции начинают проступать уже с середины 1730-х гг. Например, в 1733 г. престарелый гетман Д. П. Апостол сделал предложение в Кабинет министров Анны Иоанновны об уравнении казацких чинов с “великороссийскими” [ЭКСтРАКт 1902: 265-266].

Однако наиболее ярко они стали проявляться сгетманства К.Г. Разумовского (1750-1765). Только теперь они начинают воплощаться в новой сословно-групповой риторике. Со второй половины 1750-х гг. гетман и представители украинской казацкой элиты начинают себя позиционировать уже в качестве не казацкой старшины, апеллирующей к войсковым правам и вольностям, а малороссийской шляхты (дворянства). Этот переход в социальной риторике украинской казацкой элиты на концептуальном уровне отразил в своих историко-политических произведениях и текстах публичных выступлений видный украинский общественный деятель второй половины XVIII в. Григорий Андреевич Полетика (1725-1784).

II

Первым крупным историко-политическим сочинением, принадлежавшим руке Г. А. Полетики, стало “Возражение депутата Григория Полетики на наставление Малороссийской коллегии господину же депутату Дмитрию Натальину”. Перед тем как перейти к анализу этого документа, кратко приведем доводы его оппонентов.

“Наставление” было подписано президентом и членами Малороссийской коллегии: графом П. А. Румянцевым, генеральным обозным С. Кочубеем, князем П. Мещерским, генеральным писарем В. Туманским, полковником О. Хвостовым, генеральным есаулом И. Жоравкой, генеральным хорунжим Д. Апостолом [НАстАвлЕниЕ 1858: 70]. Таким образом, к составлению документа приложили руку и представители казацкой элиты.

В “Наставлении” “выборному от Малороссийской коллегии” давались разъяснения по различным аспектам социально-политического развития “Малой России”, в т. ч.: 1) о “главном правлении в Малой России по временам”; 2) о судах и правах; 3) “о государственных доходах"; 4) “о шляхетстве, их преимуществах и имениях"; 5) “о казаках, их свободах и имениях”; 6) “о чиновниках Малороссийских”; 7) о ду- 
ховенстве и “простом народе”. Как отмечалось в тексте документа, все разъяснения составлялись на основании архивных выписок [НАстАвление 1858: 51]. Исключительно важное место в тексте "Наставления" занимали пункты, касавшиеся украинской казацкой элиты (“малороссийской шляхты”).

В пункте “о правительстве и судах” оговаривалось, что “при вступлении Малой России под державу Всероссийских Государей жалованной грамотою” было поставлено подтвердить права Войску Запорожскому и шляхте, которой оставлялись “Суды Земские и Городские”. Однако эти суды “со временем вошли в Правления Войсковые” [НАстАвлЕниЕ 1858: 52-53]. Далее, в отношении местного “дворянства” указывалось, что, согласно Литовскому статуту и “Гетманским Статьям”, жаловать в дворянское достоинство было “предоставлено единственно власти Государевой”. Однако местные казаки, “не выключая и тех, кои из мужиков”, пользуются в судах дворянскими правами и преимуществами, а также нередко именуют себя “шляхтою”. По мнению составителей “Наставления”, дворянами могли быть признаны имеющие специальные грамоты и сохранившие дворянское достоинство, заслужившие “Государские милости, пожалования деревнями и чинами Генеральных Старшин и Полковников”, а также те, чьи предки на протяжении трех поколений были в “степенях Старшинских” [IBID.: 62].

В разделах о местных “чиновниках” и “розданных имениях коронных” также рисовалась довольно неприглядная картина. В них отмечалось, что “войсковые чиновники” по “Статьям Гетмана Хмельницкого и других Гетманов” должны были получать на содержание “уравнительно жалованье денежное”, иногда мельницы. Однако с тех пор, как на “уряды сих чинов повелено определить деревни”, в местном обществе началось сильное расслоение. Так, одни “получили великие маетности” и, пользуясь своим положением, “беспредельно обогащаются”; другие - “без нужды” могут себя содержать; третьи - “не имея никакого на содержание себя определения, впадают в лихоимство, насилия над подчиненными” [НАстАвлЕниЕ 1858: 63-64]. Но самое главное обвинение заключалось в том, что “в Малой России все почти села и деревни, Короне принадлежащие, состоят в партикулярных владениях, под именем свободных" [IBID.: 68].

В связи с этим “Возражение” Г. А. Полетики должно было дать разъяснения по самым серьезным вопросам. Свое “Возражение” Г. А. Полетика начинает с пояснений относительно “договоров”, на которых “Малая Россия” вошла в “добровольное подданство” российских царей в 1654 г. К ним он относил жалованные грамоты, которые подтверждали права Войска Запорожского, местной шляхты, духовенства и ме- 
щан. Эти “договоры” “подтверждаемы были от всех владеющих Государей при случае вступления их на престол и избрании каждого Гетмана как новыми договорами, так и жалованными грамотами”, в том числе и Екатериной II [ВозРАЖЕНИЕ 1858: 72]. Следовательно, “малороссийские права” представляли собой права четырех сословных групп, подтверждаемые российскими государями после 1654 г.

В возражении на пункт о судах Г. А. Полетика разъяснял, что практика избрания шляхтой старшин “на земские и гражданские суды” существовала до гетмана Юрия Хмельницкого (1659-1660). Однако в дальнейшем гетманы, “будучи подкреплены своею воинскою властию, которую они больше, нежели права, дозволяют”, присвоили себе не только “общенародные подати”, но и “преимущества Малороссийского шляхетства”. В результате представители шляхты, “оставив Земские чины, все стали писаться войсковым, и зависеть от единой Гетманов власти, и от сих беспредельных начальников ожидали или своего благополучия и возвышения, или, в случае их немилости, своего нещастия”. К этому Г. А. Полетика добавлял, что "разнообразность правлений и сие смещение дел [в судопроизводстве. - Я. Л.] не от чего другого произошли, как от насилия и присвоенной себе, в противность прав, власти Гетманов" [ВозРАЖЕНИЕ 1858: 74, 76]. Таким образом автор сочинения прозрачно давал понять своим оппонентам, что права, подтвержденные российскими царями, в течение долгого времени нарушались гетманами Войска Запорожского, претендовавшими на полномочия шире тех, что были за ними закреплены. Затем “антигетманские” тезисы Г. А. Полетика развивал по поводу предложений по управлению “Малой России”.

По мнению Г. А. Полетики, препоручение власти над регионом "в единственное ведомство и главное правление Генералу-Губернатору” принесет негативные последствия. Свою позицию он аргументировал следующим образом: “Вредные для всего государства, печальные для Малой России опыты доказали, сколько много оная претерпела от такового всех дел и расположений соединения и правления бывшими Малороссийскими гетманами”. Последние, присвоив “противу прав, привилегий и прежних Малороссийских вольностей все воинские, гражданские и камералные дела, поступали, как хотели, и были единственною причиною нещастливого и разорительного состояния Малой России”. Исходя из этого утверждения, Г. А. Полетика резюмировал, что при поручении генерал-губернатору правления над краем “имя только одно Гетманское отменится, а сила и действие оного останется” [ВозРАЖЕниЕ 1858: 81-82]. Конечно, в данном замечании можно заподозрить какие-то “автономистские” взгляды, если бы не одно “но”. Представитель лубенской шляхты добавлял, что, согласно "малороссийским пра- 
вам”, вся власть в регионе “единственно принадлежит Государям”. Следовательно, Г. А. Полетика прямо указывал, что гетманское правление нарушало не только права четырех “сословий”, но и права суверена.

Наиболее детально нарушения прав суверена Г. А. Полетика приводил в рассуждениях о “государственных доходах” и “чиновниках малороссийских”, где также выделял негативные стороны института гетманства. Во время присоединения “Малой России” гетман Б. Хмельницкий просил, чтобы “государственные доходы точно положены и собираемы были”. Однако “бывшие Малороссийские Гетманы”, вместо организации соборов согласно привилегии 1569 г. “княжению Киевскому”, собирали налоги “с других нововведенных статей”, употребляли их “на свои собственные расходы и обогащение, а войску никакого жалованья производимо не было, кроме охотных полков, заведенных единственно для утверждения своей власти”. Несмотря на то, что со времени правления гетмана Д. П. Апостола (1727-1734) эти сборы употреблялись на местные нужды, их положительный эффект для региона был сведен к минимуму положенными на регион сборами (постои российских войск, сборы П. А. Румянцева) и злоупотреблениями К. Г. Разумовского [ВоЗРАЖЕНИЕ 1858: 83]. ОтноситеЛьно “чиновников Малороссийских” Г. А. Полетика давал следующие пояснения. В польское время они имели “воинские права”, как и “Польские воинские чины”. Однако автор затруднялся ответить, “поступали ли они по тем правам” после вхождения региона в состав Российского государства. Автор сочинения объяснял это тем, что “Гетманы присвоили себе не токмо воинские, но и гражданские дела”. По этой причине “старшины употребляемы были как к тем, так и к другим должностям”. Последнее не могло не сказаться на привилегированном статусе местного шляхетства.

Затем Г. А. Полетика признавал, вслед за “Наставлением” Малороссийской коллегии, положительный эффект от выборности в “старшинские чины”. Однако данная практика была прекращена из-за “беспредельной власти” гетманов, которые “в старшинские чины начали производить по исканиям и своим прихотям, и по большей части людей неспособных”. Также “бывшие Малороссийские главные правители” землевладениями поощряли одних, обделяя других “воинских чиновников”. Если первое делалось согласно “правам, по которым Государь имеет власть раздавать коронные имения на чины”, то последнее - по своеволию гетманов [ВоЗРАЖЕНИЕ 1858: 94-95].

В отношении пожалования в “дворянское достоинство” Г. А. Полетика также признавал позицию Малороссийской коллегии: “по Малороссийским правам и статьям Гетманским, жаловать предоставлено одной высочайшей Государевой власти”. Однако автор не соглашался 
с тем, что в дворянском достоинстве “почитались Козаки”. Для разрешения этого вопроса, по мнению автора, следовало вникнуть "в общее право и форму правления республики Польской”. Из приведенных экскурсов следовало, что казачество, “как чин войсковой”, только судилось по нормам Литовского статута, в т. ч. и после Зборовского соглашения 1649 г., отчего казаки могли в судах "по неосторожности" именоваться и шляхтичами. В случае если "простонародные люди" “присвоивают себя к знатным и благородным фамилиям”, то таковых следовало, при наличии доказательств, “подвергать непростительному наказанию”, делая заметную оговорку относительно необходимости расширения критериев принадлежности к “шляхетству” [ВозРАжЕниЕ 1858: 90-91]. К предложенным в “Наставлении” категориям населения, могущим претендовать на шляхетство, он добавлял: 1) выходцев не из “Малой России”, которые могут подтвердить свое происхождение; 2) “всю старшину Козацкую”, так как данная группа имела принадлежность к шляхетству, начиная со Зборовского договора 1649 г.; 3) “шляхтичей”, которые не имели польских гербов, но могут доказать свои претензии через “представление” двух “сродственных себе шляхтичей” по отцовской и материнским линиям, либо, в случае прекращения рода, “посторонних шляхтичей” [IBID.: 91-92]. Несмотря на кажущееся расширение социальных границ “благородности”, в предложениях Г. А. Полетики, скорее всего, можно видеть дополнительные гарантии для казацкой элиты в подтверждении своего “шляхетства” и, соответственно, имущественного положения. Как показал Д. П. Миллер на материалах 1770-1780-х гг., попытки представителей рядового казачества достичь дворянского достоинства были обречены на провал из-за финансовых препятствий (покупка чина) и сопротивления самой элиты [МиллЕР 1897: 64-86].

Следовательно, Г. А. Полетика выступал проводником идей создания четких сословных границ, ограждавших “новую шляхту” от “примесей” из других социальных групп Гетманской Украины (прежде всего, несостоятельного казачества). Кроме того, Г. А. Полетика защищал права “новой шляхты” от посягательств со стороны местной православной церкви. По этой причине он поддержал позицию Малороссийской коллегии в вопросе запрета монастырям и лицам духовного звания (не из дворян) “приобретать каким бы то ни было образом вновь имения”, что подтверждалось, по его мнению, польскими “конституциями” 1631-1635 гг. [ВозРАЖЕНИЕ 1858: 93]. В анализе этого вопроса мы не видим апелляции к казацкому прошлому, к опыту казацкого самоуправления.

Времена до восстания гетмана Б. Хмельницкого вызывали у Г. А. Полетики наибольшую симпатию. Это наиболее ярко отраз- 
илось в его взглядах на устройство Гетманской Украины / “Малой России”.

В своем “Возражении” автор часто ссылался на те порядки, что существовали в “Малой России” в составе Речи Посполитой. Особенно ярко обращение к этому времени проявилось в рекомендации Г. А. Полетики относительно желаемого административно-территориального устройства региона. По мнению автора, “Малую Россию” следовало оставить “при старом ее и с правами сходном разделении на поветы”. Эти поветы должны были составлять два воеводства - Киевское и Черниговское [ВозРАжЕниЕ 1858: 82]. Далее автор сочинения в мельчайших деталях расписывает историко-юридическую картину развития “Малой России”. Согласно ей цари, как и польские короли, являлись суверенами над регионом, обладая правом пожалования дворянского достоинства, чинов и землевладений. "Малороссийские права” представляли собой привилегии четырех “сословий” (казачества, шляхетства, духовенства и мещанства), которые подтверждались и гарантировались российскими царями. Однако из-за особой внутриполитической ситуации в регионе права не только суверена, но и “сословий” нарушались гетманской властью. Отмеченный факт не позволяет согласиться с мнением украинского диаспорного историка 3. Когута, что Г. А. Полетика в своем “Возражении” всего лишь “критиковал наказ Малороссийской коллегии за нарушение местных прав, но и стремился доказать, что изложенные в нем предложения не нужны” [Когут 1996: 161].

Данное сочинение было не единственным в творческом багаже автора, где анализировался статус “Малой России” и “малороссийских сословий”.

Практически идентичные мысли Г. А. Полетика излагал в другом политическом сочинении - "Историческое известие, на каком основании Малая Россия была под республикою Польскою, и на каких договорах отдалась Российским Государям, и патриотическое рассуждение, каким образом можно бы оную ныне учредить, чтоб она полезна могла быть Российскому Государству без нарушения прав ее и вольностей” [ВАсиленко 1926: 55]. В этом историко-политическом произведении Г. А. Полетика повторял в более концентрированном виде те мысли, что были изложены в тексте “Возражения” и в выступлениях на заседаниях Уложенной комиссии Екатерины II. На основании польских “конституций” он утверждал, что после Люблинской унии 1569 г. местное шляхетство обладало такими же правами, что и польская шляхта. К их числу он относил в т. ч. право законода- 
тельной инициативы на региональных сеймиках ${ }^{4}$ (принятые законы они должны были представлять на конфирмации на Сейм), а также возможность “судиться прежним их правом, Литовским статутом”. Следовательно, данная социальная группа имела сословные суды, разбиравшие дела на основе Литовского статута. Более того, после 1578 г. специально для шляхты Киевского, Волынского и Браславского воеводств был учрежден свой трибунал в Луцке. Однако по просьбе местной шляхты (прежде всего, Киевского воеводства) апелляции стали рассматриваться “с прочими малопольскими воеводствами” в Люблинском трибунале. В данный трибунал направлялись избранные из местной шляхты на сеймиках “депутаты”. На уровне поветов местная шляхта имела “суды земские и градские” [IBID.: 150-151].

Кроме того, Г. А. Полетика подробно описал статус Войска Запорожского, который оно имело в составе Речи Посполитой. По мнению Г. А. Полетики, казачество было освобождено от “общенародных тягостей и податей”, а также имело право “старшину и главного полководца [гетмана. - Я. Л.] выбирать промеж себя”. Далее автор отмечал, что казачьи гетманы отличались от польских, так как “состояли всегда под их или других, от короля назначенных, командиров повелениями”. Особо отмечалось, что во время мирных переговоров с польской стороной лидер восстания - гетман Б. Хмельницкий - предлагал среди прочего “состоять под повелениями одного только короля”, а преимущества шляхты, за исключением служивших в Войске, гетманы, старшина и казаки не имели права нарушать. После данного пассажа Г. А. Полетика отмечал, что первым, кто был назначен в старшины из шляхетства (согласно польской “конституции” 1638 г.), стал И. Выговский. Последний, "отторгнувшись от России, выговорил для себя, чтобы быть всегда воеводою Киевским, а потому сенатором республики Польской” [ВАсиленко 1926: 153-154]. Таким образом, Г. А. Полетика показывал, что до присоединения к Российскому государству “Малая Россия" представляла собой территорию нескольких польских воеводств, где главную роль играла местное шляхетство и его институты самоуправления. Помимо шляхетства, особую роль играли независимые от королевской власти городские корпорации, обладавшие магдебургским правом. Институты самоуправления Войска Запорожского не имели какой-либо

4 Сеймики - органы шляхетского самоуправления в Речи Посполитой. Как правило, их было четыре вида: предсеймовый, реляционный, депутатский и элекционный. На п р е д с е й м о в о м сеймике выбирались послы на общепольский Сейм; на р е л я ц и о н н о м - выслушивались отчеты послов; на д е п у т а т с к о м - выбирались депутаты на коронный Трибунал, а также могли обсуждаться претензии, связанные с сомнительным шляхетством какого-либо шляхтича; на э л е к ц и о н н о м - выбирались или выдвигались кандидатуры для занятия/отбора на ряд земских должностей. 
власти в отношении шляхты и городов с “магдебургиями”. Более того, во время восстания Б. Хмельницкого (1648-1653) в права местных “чинов” войсковые институты власти также не имели права вмешиваться.

В отношении гетманской власти автор сочинения сохранил прежнюю критичность. Он отмечал, что “Гетман с войском [Богдан Хмельницкий. - Я. Л.], как имевшие в Малой России большую силу, договаривался о том, что им полезным быть казалось”. Однако “в договорах и одним словом упомянуть не смел”, так как знал, “на каких основаниях был под Польшею”. По мнению Г. А. Полетики, этому способствовало пожалование царских жалованных грамот местному шляхетству, духовенству и мещанам, в которые войску было запрещено вмешиваться. ${ }^{5}$ Как полагал автор, с гетманства Юрия Хмельницкого начинается “несчасливая Малой России эпоха”, так как в “договорных статьях” об особых правах шляхетства перестают упоминать. Таким образом, “гетманам открылось пространное поле к исполнению своих высокомерных и предприимчивых намерений и прихотей”, присвоив “себе шляхетству принадлежащие суды, поручили они в ведомство земские и гражданские, так, как и воинские дела, войсковой старшине, то есть сотникам и полковникам”. Следовательно, “подчинивши себе всю Малую Россию, недозволенным и беззаконным образом управляли оною по своей воле и прихотям, и не имели власти своей никакого предела”, и никто “уже не мог защищать себя своими правами и волностями”. Далее Г. А. Полетика резюмировал, что “с такою беспредельною и нагло похищенною властию похитили они [гетманы - Я. Л.] и те преимущества и пользы, которые принадлежали и принадлежат государям”. Под этими правами автор подразумевал “общую Малороссийскую казну и раздачу недвижимых имений, то есть городов, сел, земель и всяких угодий” [ВАсиленко 1926: 157-161]. Таким образом, московский царь, будучи сувереном, постепенно лишался своих суверенных прав в отношении “Малой России” вплоть до конца гетманства И. С. Мазепы. Следовательно, на протяжении второй половины XVII - начала XVIII в. шляхетские "права и вольности” были присвоены “правом сабли” украинским казачеством и старшиной, от которых их потомок, как и многие другие, дистанцировался, выдавая себя за природного шляхтича.

Однако Г. А. Полетика был не только автором историко-политических произведений, в которых обосновывал “малороссийскую” особость, обращаясь к политическому опыту польской шляхты до восстания Б. Хмельницкого. В ходе работы над проектом нового Уложения Екатерины II Г. А. Полетика также придерживался взглядов, изложенных в собственных историко-политических сочинени-

5 Здесь Г. А. Полетика практически дословно воспроизводил положения из царской жалованной грамоты Войску Запорожскому от 27 марта 1654 г. 
ях. В период работы Уложенной комиссии он проявил себя как один из наиболее активных участников. Практически все свое внимание Г. А. Полетика сосредоточил на обсуждении критериев дворянского благородства, особенно в дискуссиях вокруг известной 43-й статьи проекта Уложения “О благородных”. Как и в “Возражении”, Г. А. Полетика был озабочен проблемой расширения критериев благородства, возможностей для пожалования дворянства, а также определением преимуществ, присущих только благородному сословию. По мнению Г. А. Полетики, правом представления государю к пожалованию во дворянство следовало наделить Сенат, Военную и Адмиралтейскую коллегии, “главных над войском полководцев” и Коллегию Иностранных дел. Более того, депутат предлагал, чтобы лица полковничьего чина “без всякого представительства” могли просить о дворянстве. Следовательно, Г. А. Полетика был заинтересован в защите сословных интересов казацкой элиты, а также отстаивал проект наиболее безболезненной интеграции казацкой элиты в состав общероссийского дворянства. Далее, Г. А. Полетика высказывал мнения, которые были типичными для представителей “великороссийского” дворянства. По его мысли, следовало указать, что от податей освобождались как “благородные”, так и их дворовые; обосновать перед императрицей необходимость введения беспошлинной торговли крепостными и свободными деревнями, свободы выезда за границу; лишать имущества (“лицеимство”) поместных “благородных” только в случаях “оскорбления Величества”.

Только после этих замечаний Г. А. Полетика переходил к обсуждению статьи “О благородных” проекта нового Уложения. Здесь депутат от "малороссийского шляхетства” задал риторический вопрос: обсуждаемые статьи будущего Уложения "одному ли великороссийскому дворянству принадлежат, или других российскому скипетру присоединенных областей, в том числе и согражданам его, малороссийскому шляхетству?” На этот вопрос Г. А. Полетика давал два ответа.

В первом случае ответ был отрицательным. Причины Г. А. Полетика видел в наличии “великих несходств и недостатков" в “новосочиненных правах для благородных”. Таких несоответствий публицист насчитал пятнадцать. Остановимся на основных. По мнению малороссийского депутата, “правление дел в Малороссии, после Высочайшей государской власти, должно зависеть от шляхетства”; шляхетство должно было иметь право принятия и отмены законов в крае, но таких, которые бы вступали в силу после утверждения государем; иметь право накладывать и отменять подати; право свободы выезда и распоряжения всем имуществом; право обладать налоговым иммунитетом; 
свободно рубить лес, заниматься рыбной ловлей и охотой и т. д. Перечисленные преимущества составляли те права, которые подтвердили российские цари шляхетству и остальным “чинам” в момент присоединения “Малой России”. В противном случае Г. А. Полетика просил прибавить к 43-й статье пояснение, что “малороссийское шляхетство должно остаться при всех своих прежних правах, привилегиях, преимуществах, вольностях и свободах" [МнениЕ 1882]. Однако позиция "малороссийского шляхетства" не вызвала какой-либо реакции с “великороссийской” стороны.

Несмотря на это, отстаиваемая Г. А. Полетикой политическая позиция наводит на ряд размышлений. Эти взгляды действительно касались защиты “малороссийской” особости. Однако эта “малороссийская” особость стала результатом польского идейного трансфера, вероятно, более близкого казацкой элите. Этот идейный трансфер, воплощавший в себе исключительно польский дворянский опыт, мог быть перенесен в “великороссийскую” среду, так как Г. А. Полетика прямо высказывал данную мысль: сделать “малороссийские” / польско-шляхетские права общероссийскими. Последнее отражало готовность променять свою особость на гарантию более широкого комплекса привилегий. Следовательно, малороссийские права в представлениях и политической деятельности Г. А. Полетики становились предметом политического торга, а не воплощением некой автономистской программы. Дополнительным аргументом в пользу нашего мнения может служить письмо А. И. Чепы к сыну Г. А. Полетики - Василию (1809 г.). В нем отправитель, склоняя своего адресата к идее создания сочинения по истории “Малороссии”, высказывал интересные мысли по истории “малороссийского шляхетства”. По словам А. И. Чепы, указ Петра III “о вольности дворян” (1762 г.) и “Высочайшая грамота о дворянстве” (1785 г.) “поровняли русских дворян в преимуществах с малороссийским шляхетством, тогда малороссияне начали смело вступать в российскую службу, скинули татарские и польские платья, начали говорить, петь и плясать по-русски. . .” [Из истории 1893: 54].

Следовательно, с принятием основополагающих законов в процессе консолидации общероссийского дворянского сословия необходимость в политическом торге, касавшемся отстаивания малороссийских прав, отпала за ненадобностью. Ценой вопроса стало повышение прав российского дворянства и закрепление его исключительного положения. Заимствованный украинской казацкой элитой польский идейный трансфер под влиянием европейских идейных инноваций стал совпадать с развитием общероссийских представлений о роли дворянства 
в Российской империи. Последнее наглядно демонстрирует, что мыслимые границы допустимого в представлениях украинской казацкой элиты находились исключительно в рамках монархического дискурса (ср.: [КИСелЕв 2013: 18-53; Бугров 2013: 94-102]). На этом основании можно заключить, что лоялизм Империи со стороны казацкой элиты (малороссийской шляхты) являлся не стратегией компромисса, выработанного в условиях невозможности отстаивать некую автономию, а вполне сознательной стратегией поддержания элитарного статуса.

Таким образом, дискуссии о правах, привилегиях, свободах и обязанностях дворянства, в которых активно участвовал Г. А. Полетика, не могли породить радикально нового политического языка, который потенциально поставил бы под сомнение целостность Российской империи. В них отсутствовал общий для всех малороссийских сословных групп идеал некой “Гетманской Украины” или независимости “Украинской казацкой державы”, а также отсутствовали переживания по поводу утраты “украинской государственности”. Не присутствовали в текстах Г. А. Полетики и апелляции к казацкому (войсковому) прошлому, которое признается по большей части “несчастливой эпохой”, в отличие от польского времени.

Реконструированное нами идейное поле “национального” интеллектуала вряд ли позволило бы деятелям уже в XIX в. запустить проекты строительства современной украинской нации. В связи с этим следует говорить о наличии определенных разрывов в процессе нациестроительства, когда не элита творила национальный миф, а далекая от нее интеллигенция. Причина этого, на наш взгляд, коренилась в том, что украинская элита второй половины XVIII - начала XIX в. была заинтересована в поддержании своего элитарного статуса. Последнее, с частыми оговорками, признается и в современной украинской историографии [ПлохІй 2013: 20, 399].

\section{Библиограсьия}

\section{Печатные источники}

ВАСИЛЕНКО 1926

ВАсилЕнко Н. П., “Збірка матеріялів до історії Лівобережної України та українського права XVII-XVIII вв.”, в: Украйнський археографічний збірник, 1, Київ, 1926, 50-164.

ВОЗРАЖЕНИЕ 1858

"Возражение депутата Григория Полетики на наставление Малороссийской коллегии господину же депутату Дмитрию Натальину”, в: Чтения в Императорском Обществе истории и древностей российских при Московском университете, 3, 1858, 1-102.

ГРАмотА 1956

ПЕтP I, “Грамота гетману И. И. Скоропадскому (5 января 1710 г.)”, в: Б. Б. КАФЕНГАУз, ред., Письма и бумаги императора Петра Великого, 10: январь-декабрь 1710 г., Москва, 1956, 9-12. 
The Ideological Basis of the "National" Intellectuals of the Imperial Period:

The Views of G. A. Poletika (1725-1784) on "Ukrainian Statehood"

Из истории 1893

“Из истории южно-русского общества начала XIX века (письма В. И. Чарныша,

А. И. Чепы, В. Г. Полетики и заметки к ним)”, Киевская старина, 1, 1893, 41-76.

МнЕнИе 1882

“Мнение Гр. Полетики на проект правам благородных”, в: Сборник Императорского Русского исторического общества, 36, С.-Петербург, 1882, 346-354.

НАСТАВЛЕНИЕ 1858

“Наставление выборному от Малороссийской коллегии в Комиссию о сочинении проекта новаго Уложения, г. коллежскому советнику и члену той коллегии Наталину”, Чтения в Императорском Обществе истории и древностей российских при Московском университете, 3, 1858, 44-74.

ЭКстРАКт 1902

“Экстракт из указов, инструкций и учреждений, с разделением по материям, на двенадцать частей: собрано в Правительствующем Сенате по малороссийской экспедиции, 1786 г.", в: Материаль для истории экономического, юридического и общественного быта Старой Малороссии, 2, Чернигов, 1902, 1-296.

\section{Литература}

\section{Бугров 2013}

Бугров К. Д., “«Палладиум России»? Монархизм как дискурс российской модерности”, Былые годы, 30 (4), 2013, 94-102 (электронный ресурс; режим доступа: http://bg.sutr.ru/ journals_n/1387426755.pdf; последнее обращение: 15.07.2016).

ЕКЕЛЬчИК 2010

Екельчик С., Українофіли: світ українських патріотів другой половини ХІХ століття, Київ, 2010.

ЖУРБА 2009

ЖурьА О. І., “«Представте вы себе, какой зверь был Гетман! Это были пренечестивые деспоты!» (з листа свідомого українського патріота, автономіста та традиціоналіста початку XIX століття)", в: О. І. ЖурБА, ред., Дніпропетровський історико-археографічний збірник, 3: На пошану проф. А. Г. Болебруха, Дніпропетровськ, 2009, 161-220.

КАГАНОВ 1966

КАГАНОВ И. Я., “Г. А. Полетика и его книжные интересы (Из истории книжной культуры XVIII в.)”, в: Д. С. ЛИХАЧЕв, Г. П. МАКОГОНЕНКО, И. З. СЕРМАН, ред., XVIII век, 7: Роль и значение литературы ХVIII века в истории русской культуры. К 70-летию чл.-корр. АН СССР П. Н. Беркова, Москва; Ленинград, 1966, 138-144.

КИСЕЛЕВ 2013

Киселев М. А., “Форма правления и социальная иерархия в российской политической мысли XVII - первой четверти XVIII века”, Исторический вестник, 6 (153), 2013, 18-53.

Когут 1996

Когут 3. Е., Російський централізм і українська автономія: ліквідація Гетьманщини (1760-1830), Київ, 1996.

ЛАЗАРЕВ 2013A

ЛАЗАРЕВ Я. А., “«Ласковый телок двух маток сосет»: к вопросу о природе украинской государственности во второй половине XVII - первой трети XVIII вв. (в порядке дискуссии с Т. Чухлибом)”, Исторический вестник, 4 (151), 2013, 206-218. 
2013Б

ЛАЗАРЕВ Я. А., “«К вашей ясневелможности охочий слуга»: к вопросу о функционировании неформальных связей в российско-украинских отношениях в 20-е - первой половине 30-х гг. XVIII в.”, в: А. В. ДоРОНИН, Н. Н. ПЕтрУХИнцЕв, Л. ЭРРен, ред., Правящие элиты и дворянство России во время и после петровских реформ (1682-1750), Москва, 2013, 408-432.

ЛитвиновА 2015

ЛитвиновА Т. Ф., “Григорий Андреевич Полетика «публичный интеллектуал» второй половины XVIII в.”, Вестник Омского университета. Серия “Исторические науки”, 2 (6), $2015,79-86$.

МЕльник 2003

МЕльник Л. Г., “Гетьманщина в історико-публицистичних творах Григорія Политики”, Український історичний журнал, 6 (453), 2003, 132-143.

МиллеР 1897

МиллеР Д. П., Очерки из истории и юридического быта старой Малороссии: превращение козацкой старшины в дворянство, Киев, 1897.

Плохій 2013

ПлохІй С. М., Козацький міф. Історія та націєтворення в епоху імперій, М. Климчук, авториз. пер. з англ., Київ, 2013.

Руднев 2015

Руднев Д. В., “Григорий Андреевич Полетика и его педагогическая деятельность”, в:

И. И. ФЕдюкин, М. Б. ЛАвринович, ред., Регулярная академия учреждена будет. . .: Образовательные проекты в России в первой половине XVIII века, Москва, 2015, 363-399.

Хрох 2002

Хрох М., "От национальных движений к полностью сформировавшейся нации: процесс строительства наций в Европе”, в: Б. Андерсон ет AL., Нации и национализм, Л. Е. ПЕРЕяСЛАвЦЕвА, М. Б. ГНЕДОВСКОЙ, пер. с анГЛ., М. С. ПАНИН, Пер. с нем., Москва, 2002, 121-144.

\section{References}

Bugrov K. D., “'The Palladium of Russia?’ Monarchism as a Discourse of Russian Modernity," Bylye Gody, 30 (4), 2013, 94-102.

Ekel'chyk S., Ukraïnofily: svit ukraïns kikh patriotiv druhoi polovyny XIX stolittia, Kiev, 2010.

Hroch M., "From National Movement to the Fully-Formed Nation: The Nation-Building Process in Europe," in: B. Anderson et al., Mapping the $\mathrm{Na}$ tions, Russian translation by L. E. Pereyaslavtseva, M. B. Gnedovskoy, M. S. Panin, Moscow, 2002, 121-144.

Kaganov I. Ya., “G. A. Poletika i ego knizhnye interesy (Iz istorii knizhnoi kul'tury XVIII v.),” in: D. S. Likhachev, G. P. Makogonenko, I. Z. Serman, eds., XVIII vek, 7: Rol' i znachenie literatury XVIII veka $v$ istorii russkoi kul'tury, Moscow, Leningrad, 1966, 138-144.

Kiselev M. A., "Forms of Government and Social Hierarchy in Russian Politics of the XVII and the
First Quarter of the XVIII Centuries," Historical Reporter, 6 (153), 2013, 18-53.

Kohut Z. E., Rosiis'kyi tsentralizm i ukraïns'ka avtonomiia: likvidatsiia Het'manshchyny (1760-1830), Kiev, 1996.

Lazarev Ya. A., “'Laskovyi telok dvukh matok soset': k voprosu o prirode ukrainskoi gosudarstvennosti vo vtoroi polovine XVII - pervoi treti XVIII vv. (v poriadke diskussii s T. Chukhlibom)," Historical Reporter, 4 (151), 2013, 206-219.

Lazarev Ya. A., “'K vashei iasnevelmozhnosti okhochii sluga': k voprosu o funktsionirovanii neformal'nykh sviazei $\mathrm{v}$ rossiisko-ukrainskikh otnosheniiakh v 20-e - pervoi polovine 30-kh gg. XVIII v.," in: A. V. Doronin, L. Érren, N. N. Petrukhintsev, eds., Ruling Elites and the Nobility in Russia during and after the Reforms of Peter the Great (1682-1750), Moscow, 2013, 408-432. 
Litvinova T. F., "G. A. Poletika: 'Public Intellectual' of the Second Half of the XVIII Century," Herald of Omsk University. Series "Historical Studies", 2 (6), 2015, 79-86.

Mel'nik L. H., "Het'manshchyna v istorykopublytsystychnykh tvorakh Hryhoriia Polytyky," Ukrainian Historical Journal (= Ukraiinsky Istorychny Zhurnal), 6 (453), 2003, 132-143.

Plokhy S., The Cossack Myth: History and Nationhood in the Age of Empires, Ukrainian translation by M. Klymchuk, Kiev, 2013.
Rudnev D. V., "Gregory A. Poletika as a Pedagogue”, in I. I. Fedyukin, M. B. Lavrinovich, eds., "Reguliarnaia Akademiia Uchrezhdena Budet...": Educational Projects in Russia in the First Half of the XVIII Century, Moscow, 2015, 363-399.

Zhurba O. I., "'Predstavte vy sebe, kakoi zver'byl Getman! Eto byli prenechestivye despoty!' (z lysta svidomoho ukrains'koho patriota, avtonomista ta tradytsionalista pochatku XIX stolittia)," in: O. I. Zhurba, ed., Dnipropetrovs kyi istoryko-arkheografichnyi zbirnyk, 3: Na poshanu prof. A. G. Bolebrukha, Dnepropetrovsk, 2009, 161-220.

\section{Acknowledgements}

Supported by Act 211 Government of the Russian Federation, agreement No. 02.A03.21.0006.

Яков Анатольевич Дазарев, канд. истор. наук

Уральский федеральный университет

им. первого Президента России Б. Н. Едьцина,

научный сотрудник Даборатории эдиционной археографии

Института гуманитарных наук и искусств

620083 Екатеринбург, ул. Тургенева, д. 4

Россия/Russia

9lazarev@gmail.com 